\title{
Chapter 12 \\ Planning Major Transport \\ Infrastructure: Benefits and Limitations \\ of the Participatory Decision-Making \\ Processes
}

\section{Maruša Goluža}

\begin{abstract}
Although stakeholder participation has been considered an ideal approach in spatial planning theory since the 1980 s, decision-making processes are not always so inclusive in practice. Planning major transport infrastructure is usually a very contentious, time-consuming, and extremely demanding task due to a myriad of stakeholder interests and power relations that accompany decision-making processes. In order to determine the benefits and limitations of stakeholder participation when planning major transport infrastructure, this study analyzes and compares the planning processes of two freeway sections in Slovenia. It applies a qualitative document analysis method to reveal the background and developments of Slovenian infrastructure planning through history. The results show that both decision-making processes analyzed indicate a democratic deficit, which is a consequence of unfavorable institutional arrangements and legislation, and tokenistic planning tradition. The openness of decision-making processes has remained dependent on decisionmakers' (usually national institutions') preferences. Both of the decision-making processes studied also lack legitimacy and are biased by the power relations among stakeholders. The main contribution of this chapter is a more thorough understanding of the benefits and limitations that accompany stakeholder participation in planning major infrastructure, which may enhance the efficiency of future decision-making processes.
\end{abstract}

Keywords Infrastructure development $\cdot$ Conflicts of interest $\cdot$ Deliberative democracy $\cdot$ Communicative planning $\cdot$ Power relations

\subsection{Introduction}

Planning major infrastructure is usually a time-consuming and challenging task because these projects are generally large-scale and financially demanding, with long-term and irreversible consequences. Consequently, infrastructure planning concerns a large number of stakeholders, whose stakes in planning and policy-making are

M. Goluža (更)

Research Centre of the Slovenian Academy of Sciences and Arts, Anton Melik Geographical Institute, Ljubljana, Slovenia

e-mail: marusa.goluza@zrc-sazu.si

(C) The Author(s) 2020

J. Nared and D. Bole (eds.), Participatory Research and Planning in Practice,

The Urban Book Series, https://doi.org/10.1007/978-3-030-28014-7_12 
usually very high. They range from national, regional, and local economic interests and conservationist interests (e.g., nature, cultural heritage, and agriculture) to very individual existential interests (usually expressed as opposition to noise, pollution, or even loss of a home). There is a strong connection between road construction and spatial and regional development, which raises the stakes in infrastructure planning. One of the main underlying goals behind infrastructure construction is usually tackling uneven spatial and economic development (e.g., Committee on Spatial Development 1999; Dühr, Colomb and Nadin 2010; European Commission 2011). According to Peters (2003), investments in various transport options are always also investments in different spatial development futures. Infrastructure is commonly presented as a generator of economic growth, as well as economic and social cohesion, which is why infrastructure holds an important position in strategic documents connected with spatial development, both supranational (e.g., Committee on Spatial Development 1999) and national, such as the Spatial Development Strategy of Slovenia (2004). This developmental role has remained the main rationale behind infrastructure planning in the European Union and worldwide, even though it has been proven that many such projects have strikingly poor performance records in terms of the economy, the environment, and public support (Flyvbjerg et al. 2003; Crescenzi and RodriguesPosé 2012). Transport infrastructure as longitudinal projects also cuts across various administrative layers (i.e., national, regional, and local), different land uses under the domain of different sectoral policies, and, last but not least, individuals' private property. Harmonizing, the entire range of interests in infrastructure planning is thus inevitably a strikingly demanding task for spatial planners.

Due to such a variety of stakeholders that are affected by infrastructure projects, conflicts are usually an integral part of planning procedures. Peters (2003, p. 317) illustrated the conflict-prone character of infrastructure planning with a European Commission statement from 1994 that says: "transport is many things to all people." At first glance, this rather ambiguous statement quite clearly points out the main challenge in decision-making procedures in infrastructure planning. Stakeholders perceive infrastructure differently and thus do not have the same views on what the right decision is. The great variety of stakeholders' perceptions and distinctively high stakes makes decision-making in infrastructure planning highly contentious. Conflicts as an integral part of infrastructure planning make stakeholder participation an indispensable part of every legitimate decision-making processes.

This chapter reveals the main characteristics of stakeholder participation in infrastructure planning, set in the context of specific sociopolitical changes that Slovenia faced after gaining independence in 1991. It analyzes the benefits and limitations of stakeholder participation through the lens of contentious situations that generally accompany decision-making procedures in the transport sector. The freeway project that started while Slovenia was still part of Yugoslavia is one of the largest infrastructure projects in Slovenia, and it played a strong integrating and state-formation role. Public support for this project was relatively high in the initial stages of carrying out the project, but through the course of its realization, it became increasingly conflict-laden. After independence, the Slovenian spatial planning system and infrastructure planning in particular struggled with several challenges: the growing number 
of municipalities, privatization, greater interest of residents in participating in decisions on public matters, the ineffectiveness (or even the absence) of harmonization measures (such as public hearings), and the absence of a regional administrative level as an intermediate between local and national interests. Several researchers have questioned the quality of democracy and the process of Europeanization in post-communist countries (for a more thorough literature review, see Coman and Tomini 2014). They argue that post-communist countries lag behind their western European counterparts in terms of participation (Coman and Tomini 2014) and that their communist history has had a major influence on the understanding of and trust in democracy. This study analyzes two case studies from Slovenia whose time span stretches through most of the history of Slovenian infrastructure planning. It contrasts spatial planning legislation and participatory planning practice from the transitional times of the 1990s to today when Slovenia is presumed to have adopted western norms. The two case studies reveal what the role of stakeholder participation has been in infrastructure planning in Slovenia after the transition and how it fits into broadly accepted standards of good participatory decision-making processes.

\subsection{Slovenian Infrastructure Planning Before Independence}

This study is set in a Slovenian context, characterized by the transition from the communist era to democracy after independence in 1991. Transition is primarily a political process (Offe 1997) that is accompanied by the democratization of civil and political society, the state's legal order, the institutional apparatus, and the economy (Thomas 1998). Each country's path of transition may differ and is influenced by the past (i.e., it is path-dependent; Thomas 1998). After the Second World War, the Yugoslav constitutional monarchy was succeeded by a communist regime with central command planning that underpinned socioeconomic development (Vujošević and Nedović-Budić 2006). At that time, collective interests gained power, and spatial resources (except rural properties smaller than ten hectares) became state property (Perić 2016). Until 1967, spatial planning as a profession in Slovenia was mostly oriented toward urbanism rather than spatial planning in general (Ravbar 2007).

In 1967, Slovenia adopted its first law on regional and spatial development. Regional and spatial planning became part of social planning and was harmonized with economic planning and projections. The law was quite advanced, even in a wider European context, in a sense that it introduced democratic principles in decision-making procedures (Saje 1967). Planning processes were consensus-based and opened not only to sectoral interests, professionals' knowledge, and representatives of local politics, but also to public stakeholders (Saje 1967). Nevertheless, this collaborative principle faced several obstacles in practice. First, the law lacked a clear methodology for realizing stakeholder participation (Pogačnik 2005), and, second, politics significantly influenced decisions. The Communist Party, at that 
time, the only political party in the state, controlled all associations (professional and civil), which is why hardly any decision was made without its involvement and prior consent (Perić 2016).

Infrastructure planning in Yugoslavia played an important role in economic and social development from 1960 onward. In 1970, Slovenia finally adopted its first regional spatial plan, which emphasized the importance of infrastructure for anticipated economic development and the emerging model of the polycentric settlement system. The rationale behind infrastructure planning in Slovenia was to provide citizens with equal opportunities to choose a place of residence, work, shopping, and recreation (Regional spatial plan ... 1970). These trends of decentralization, growth of new industrial urban centers, and the goal of equal accessibility to various services can be understood in the light of territorial justice, which resonated well with the dominant social ideology of egalitarianism that was prominent in Yugoslavia (Luthar and Pušnik 2017).

The first $32 \mathrm{~km}$ of freeways were built in 1972. Even though Yugoslavia mostly encouraged infrastructure connections within its federal borders, Slovenia considered and planned infrastructure that would also make possible connections with more developed countries of western and central Europe. The freeway project, the largest infrastructure project in Slovenia's history, had a strong state-forming role, which contributed to high public support for the project (Kos 2003). Notwithstanding this public acceptance, however, Slovenian freeways were not built without conflicts. The conflicts were more latent because the political system did not allow overt opposition, especially among the public.

\subsection{Slovenian Infrastructure Planning After Independence}

After independence in 1991, Slovenia continued its freeway project. The majority of freeways were built based on the National Freeway Construction Program (1995), in a new post-communist context. Key challenges that Slovenian spatial planning faced after the transition to democracy were, as already stated, the local government reform followed by the growing number of municipalities, privatization, broader public engagement in planning procedures and the expansion of initiatives, the ineffectiveness (or even absence) of harmonization measures (such as public hearings), and the absence of a regional administrative level as an intermediate between local and national interests. The local government reform in 1994 gave municipalities autonomy for spatial planning in their territory, and it gave residents of Slovenia the right to participate in public matters (Vlaj 1998). The subsequent legislation in local self-government permitted the fragmentation of the existing system, which resulted in a growing number of new municipalities (from 147 in 1994 to 212 in 2017). This significantly affected planning procedures not only due to the increased number of (local) interests that needed to be harmonized, but also due to the prevailing 
tendency of many municipalities to pursue local competitiveness goals instead of carrying out projects in the national interest (such as freeways; Kos 2002; Ravbar 2016). Major infrastructure projects are, nevertheless, still primarily in the domain of the state. Vertical differentiation (Bartos and Wehr 2002) between the national and local administrative levels is often the fundamental source for conflict in infrastructure planning. In relation to this national versus local divide, the absence of a regional administrative level in Slovenia encumbers the harmonization of interests. Another challenge for planning procedures in the newly established country was the privatization and general higher engagement of individuals in decision-making procedures. This strengthened the dynamics of civil initiative formation and encouraged individuals to more explicitly demand the right to participate in decision-making processes and influence final decisions. The absence of sufficient measures for harmonizing interests in the Slovenian spatial planning system, limited to public hearings and public displays, exacerbated the legitimacy crisis in spatial planning and clearly showed the need for more context-sensitive planning practices.

Until 2002, Slovenia had only provisional interim spatial planning legislation that served for the realization of sectoral plans such was the freeway project (Nared et al. 2019). The first Slovenian law on spatial planning was the Spatial Management Act (2002), which implemented the public hearing as an instrument to harmonize various stakeholder interests in the decision-making process. The law provided the public hearing as an instrument to harmonize interests among national institutions, local authorities, interest groups, and economic entities. The general public in a broader sense had the right to criticize and react to national spatial plans already made by government agencies at public displays in the later stages of decision-making procedures. Although the public hearing was a promising step forward in terms of stakeholder inclusion in planning procedures, such a measure still corresponds to a degree of tokenism on Arnstein's ladder of citizen participation (Arnstein 1969). The decisions are still mainly in the hands of more influential, powerful stakeholders, and participatory procedures are limited to informing the public, consultation, and placation (Arnstein 1969). However, with the Spatial Planning Act adopted in 2007, the public hearing was removed from planning legislation as an obligatory part of the decision-making process. The main intent of this step was to accelerate planning procedures, but with no success. This measure even strengthened the domination of national institutions in spatial planning in general and, consequently, in infrastructure planning as well. The participation of sectoral ministries was reduced to providing an expert background for preparing the national development plan and limitations regarding the planned structure. Each ministry provided materials for its own professional field, with no formal instrument in the procedure allowing the harmonization of incompatibilities among them. Other stakeholders and the public were given an opportunity to object, criticize, or support national development plans no sooner than at public displays, when the national development plan had already been made.

In 2010, this less-than-beneficial move, the removal of the public hearing, was partially corrected with the adoption of another law, the Siting of Spatial Arrangements of National Importance Act (2010), which only addressed planning of structures of national interest, including infrastructure projects. The public hearing 
again became obligatory, but only to harmonize the interests of national institutions (e.g., ministries), not the other stakeholders and the general public. Objection and appeal procedures for other stakeholders and the general public retained their position in public displays at the end of decision-making procedures. According to Nared et al. (2015), such provisions provide a false impression that every planning decision is made with public consent. In practice, the public is deprived of the opportunity to contribute to plans and decisions about its own future and living environment (Nared et al. 2015).

Major transport infrastructure is an immense intervention in a natural environment. Commonly, these are financially and technically very demanding projects that cause permanent loss of land. Although transport infrastructure brings several advantages to wider society, it may also be very disturbing, especially for local communities (e.g., worsened quality of life, change of residence, demolition of homes, noise, etc.; Škarabot 2002). Decisions about future transport infrastructure are thus highly complex and cannot be legitimate without opening decisionmaking procedures to a wider circle of stakeholders and the public. In contrast to this stance, the common reaction of national authorities to the complexity of major infrastructure planning is usually the simplification of planning procedures (Salet et al. 2012). An example of such simplification in Slovenia was the Spatial Planning Act (2007), which attempted to lower the number of stakeholders included in decision-making procedures, but with quite the opposite effect. Such measures may cause vigorous reactions of excluded stakeholders (e.g., the NIMBY effect), obstruct a constructive dialog among stakeholders, and hinder finding an appropriate solution of the conflict. As a consequence, the mere decision-making procedure may thus be prolonged, become more expensive or even be impossible to complete (Škarabot 2002; Salet et al. 2012).

In 2018, Slovenia adopted its latest spatial planning legislation, which again promotes earlier inclusion of relevant stakeholders in the decision-making process (Spatial Planning Act 2 2017). It also provides the legal basis for preparing inter-municipal spatial plans. However, participatory approaches to planning processes as well as inter-municipal collaborations are not legally binding. Instead, they are more or less voluntary optional choices.

\subsection{Methods and Materials}

This study analyzed decision-making procedures in infrastructure planning in Slovenia in order to define the advantages and obstacles that accompany stakeholder participation in infrastructure planning. The choice of case studies (Fig. 12.1) was chronologically driven because the goal was to cover as much as possible during the time span of Slovenian infrastructure planning. The reason behind this decision stems from the fact that Slovenian spatial planning had to operate in different sociopolitical contexts. As already described in the previous section, changing sociopolitical contexts in the history of Slovenian spatial planning conditioned the changing role 


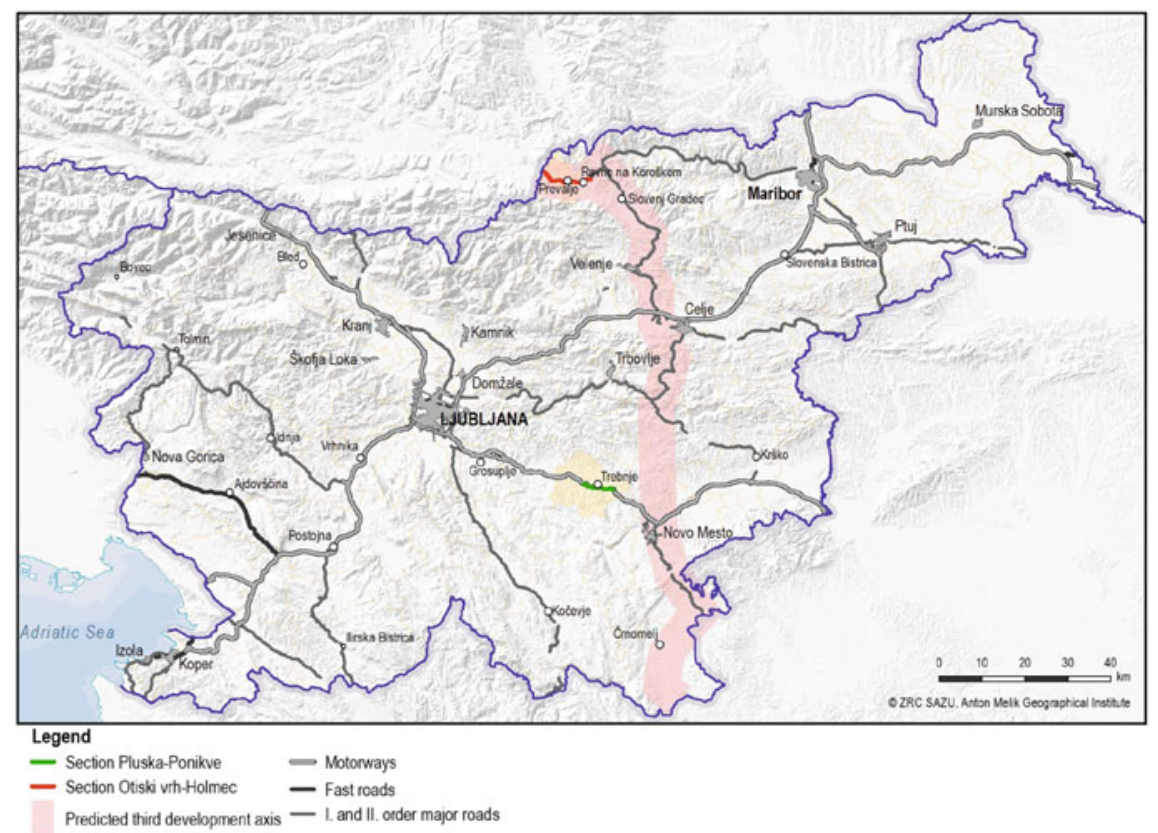

Fig. 12.1 The Slovenian road network with the two case studies

of stakeholders and revealed some advantages and limitations that accompany their participation. The first case study therefore is the Slovenian freeway section from Pluska to Ponikve, which was started in the 1960s. The decision about the future route was made in 2006 under pressure from more powerful stakeholders. The section was built in 2010. The decision-making procedure for the second case study, the section from Otiški Vrh to Holmec on the third development axis, started in 2002. Due to the opposition of local communities to the proposed route, the Ministry of the Environment and Spatial Planning decided to open the decision-making process to the general public. This was in some way a precedent in Slovenia in terms of stakeholder inclusion in the decision-making procedure. Despite the willingness of the ministry to attain a consensual decision that would be accepted in the local environment, the procedure was postponed due to unresolvable differences among the locals and national institutions.

The first case study is the Slovenian freeway section from Pluska to Ponikve. The first plans for Slovenian freeways were created in the 1960s, but the decisionmaking process for the section from Pluska to Ponikve actually started in 1995 and was finished in 2010. The second case study is more recent planning of the third development axis. The study analyzed its northern part, the section from Otiški Vrh to Holmec. The third development axis was first mentioned in the long-term plan for 1986 to 2000, published in 1986. The decision-making process actually started much later, in 2004, and has not yet been realized. 
To define the advantages and possible obstacles that supplement stakeholder participation throughout decision-making processes, a document analysis method was applied, which is useful in cases when there is interest in a historical context or when the goal is to provide a background and track the changes to or development of some phenomena (Bowen 2009). Because both case studies were quite contentious and notorious, it was decided to use only documents that are kept by the Ministry of the Environment and Spatial Planning, such as studies of variants, minutes from meetings with stakeholders, the results of inquiries (if carried out), and so on. The documents from the ministry for both case studies are consistent and relatively comparable. They are also relatively neutral in comparison to newspaper articles or other references from the media. All materials were obtained at the Ministry of the Environment and Spatial Planning in spring 2017. For a better understanding of both case studies, Slovenian spatial development legislation was also analyzed as a legal basis that defines the outline of decision-making procedures and determines the role of stakeholders. There are, however, also some limitations to the research method chosen. The main concern of the document analysis is the issue of bias, which can be twofold: first, the documents can be influenced by the "writer's" viewpoints and positions, and, second, the researcher's assumptions, values, and interests may influence the research process (Karppinen and Moe 2014).

The information that was sought in documents was which stakeholders participated in the planning procedure (or were able to participate), key events that changed stakeholders' positions, and how decisions were made and by whom. This information is presented in Tables 12.1 and 12.2, which also indicate which planning law was in force at that time (in different colors).

\subsection{Results}

The main characteristics of the planning processes in both case studies are chronologically presented in Tables 12.1 and 12.2. Each table shows the main events in both decision-making processes and its short description with an emphasis on relations among (conflicting) stakeholders.

\subsubsection{First Case Study: The Freeway Section from Pluska to Ponikve}

The first case study, the freeway section from Pluska to Ponikve, is one of the latest freeway sections in Slovenia. The major challenge in the planning procedure was selecting the final route among three different options, named after their location:

- The route alongside Trebnje, a route that was supposed to replace the existing regional road passing Trebnje; 
12 Planning Major Transport Infrastructure ...

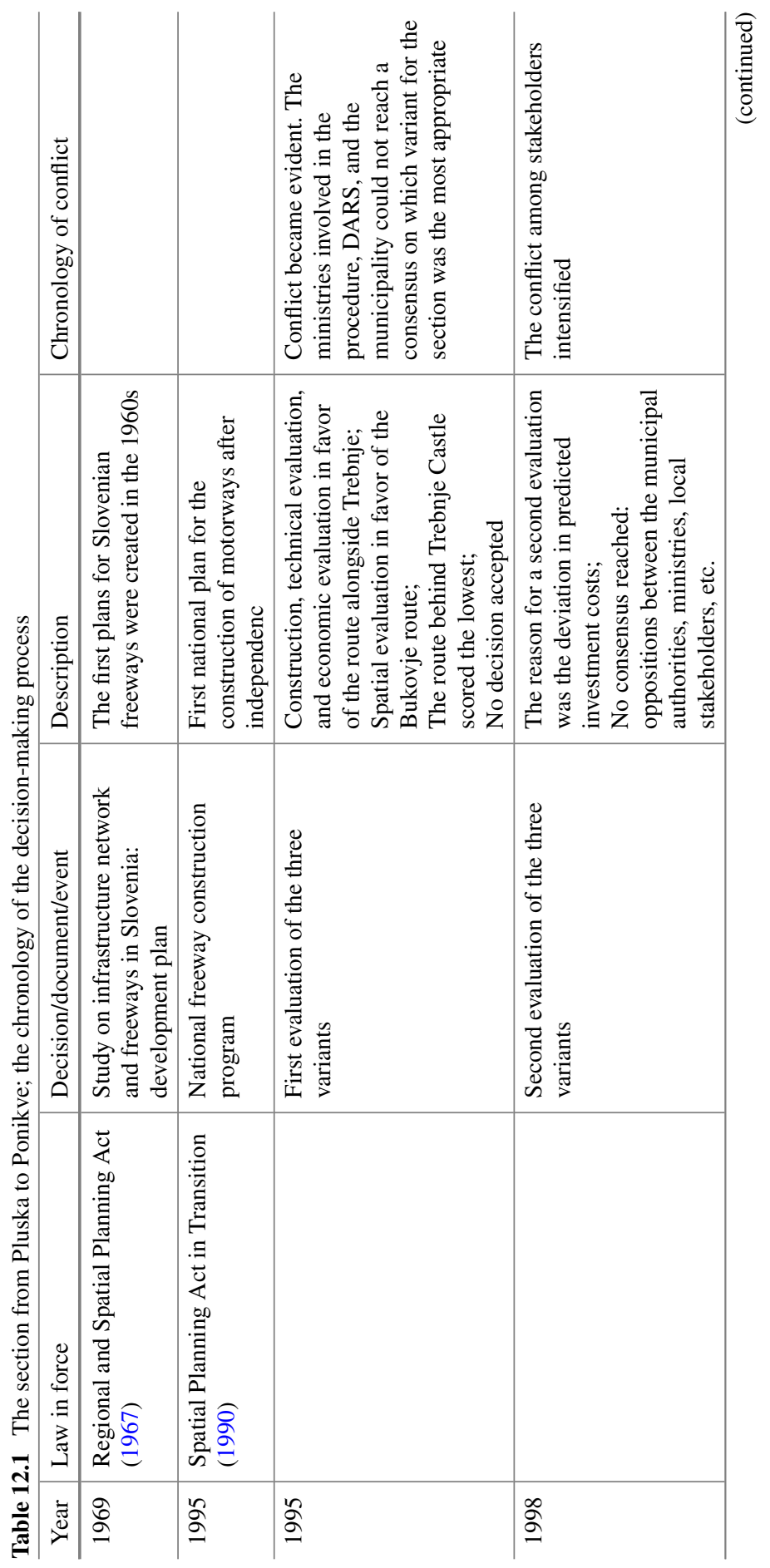




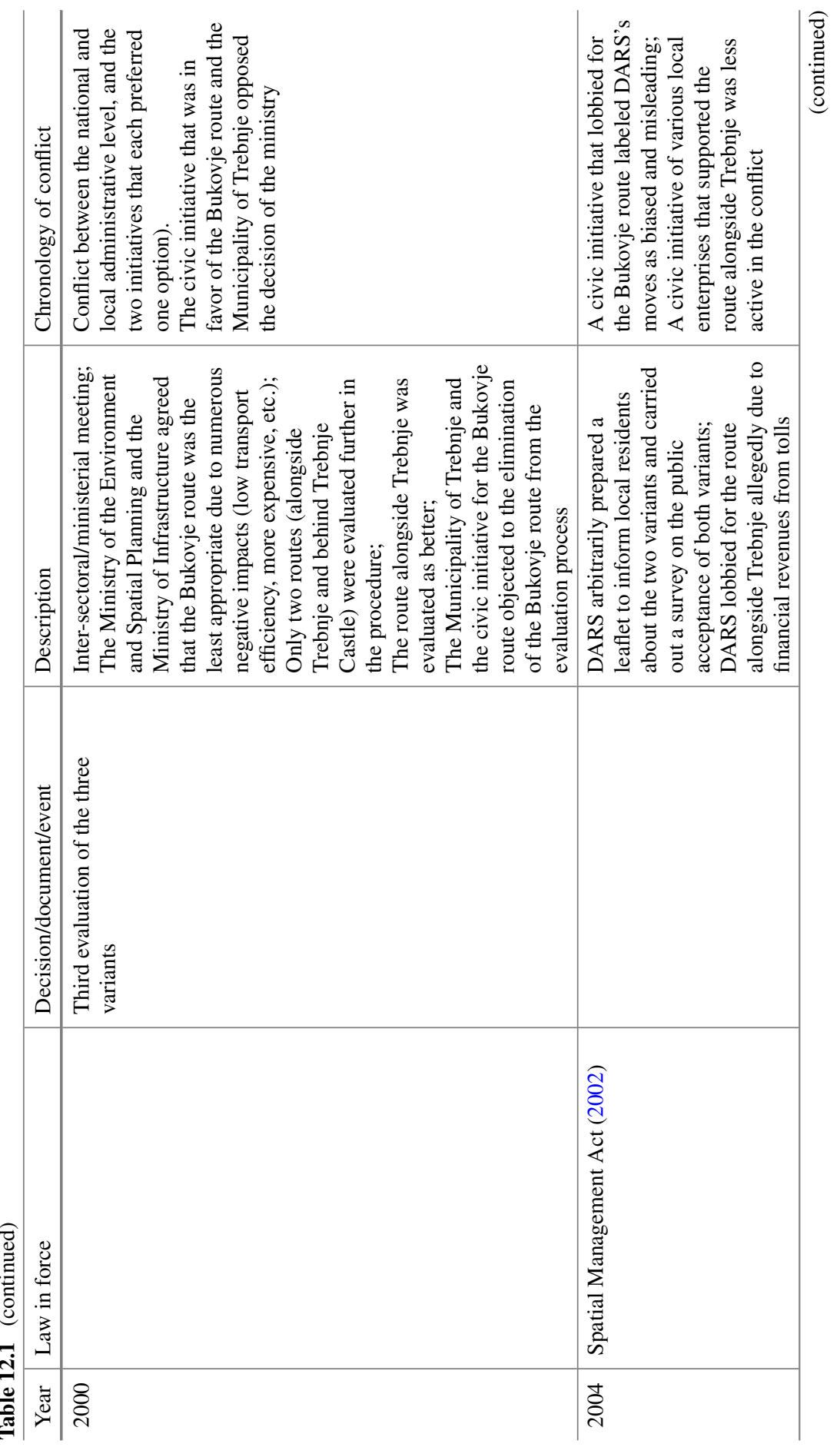


12 Planning Major Transport Infrastructure ...

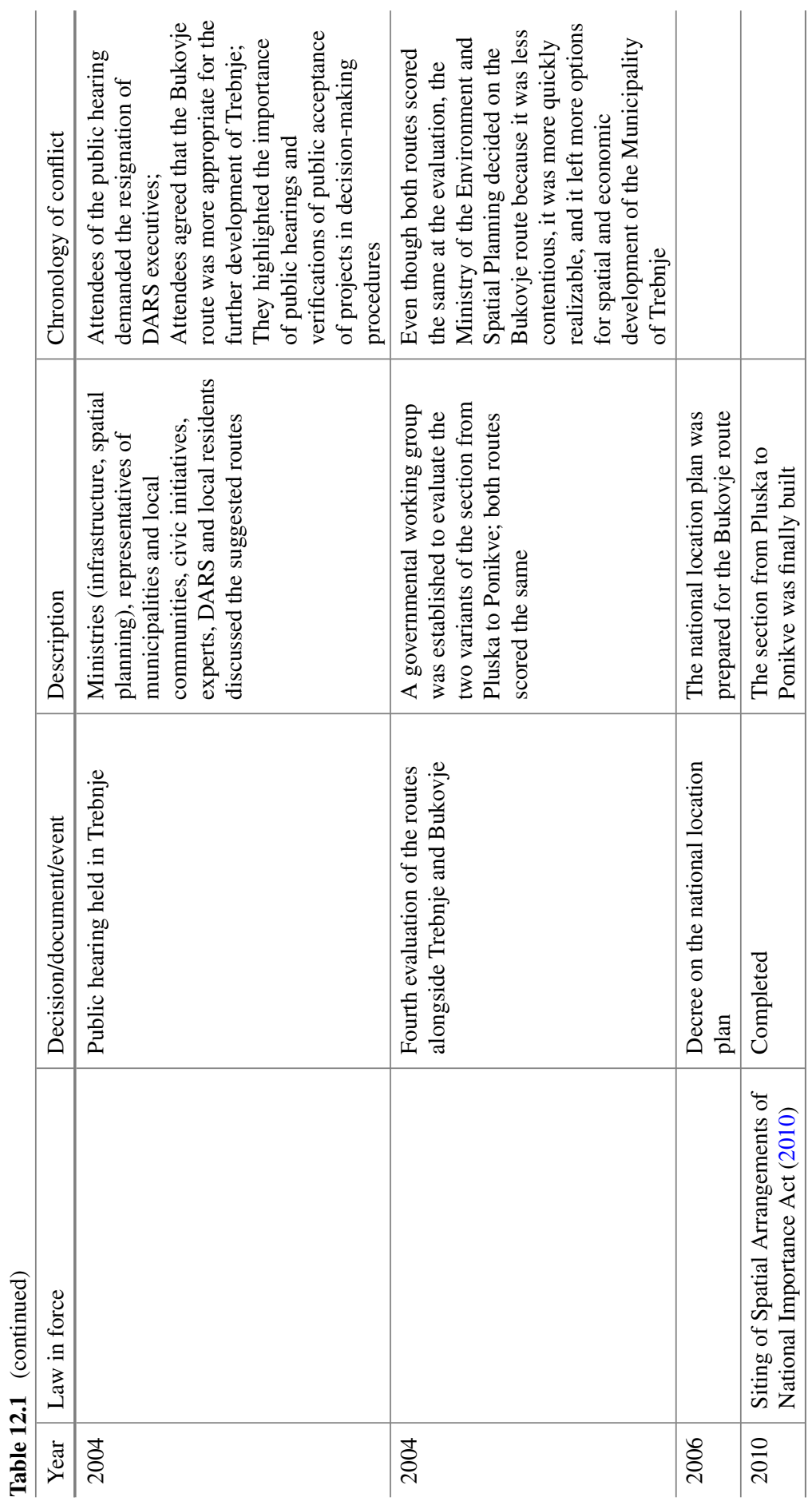




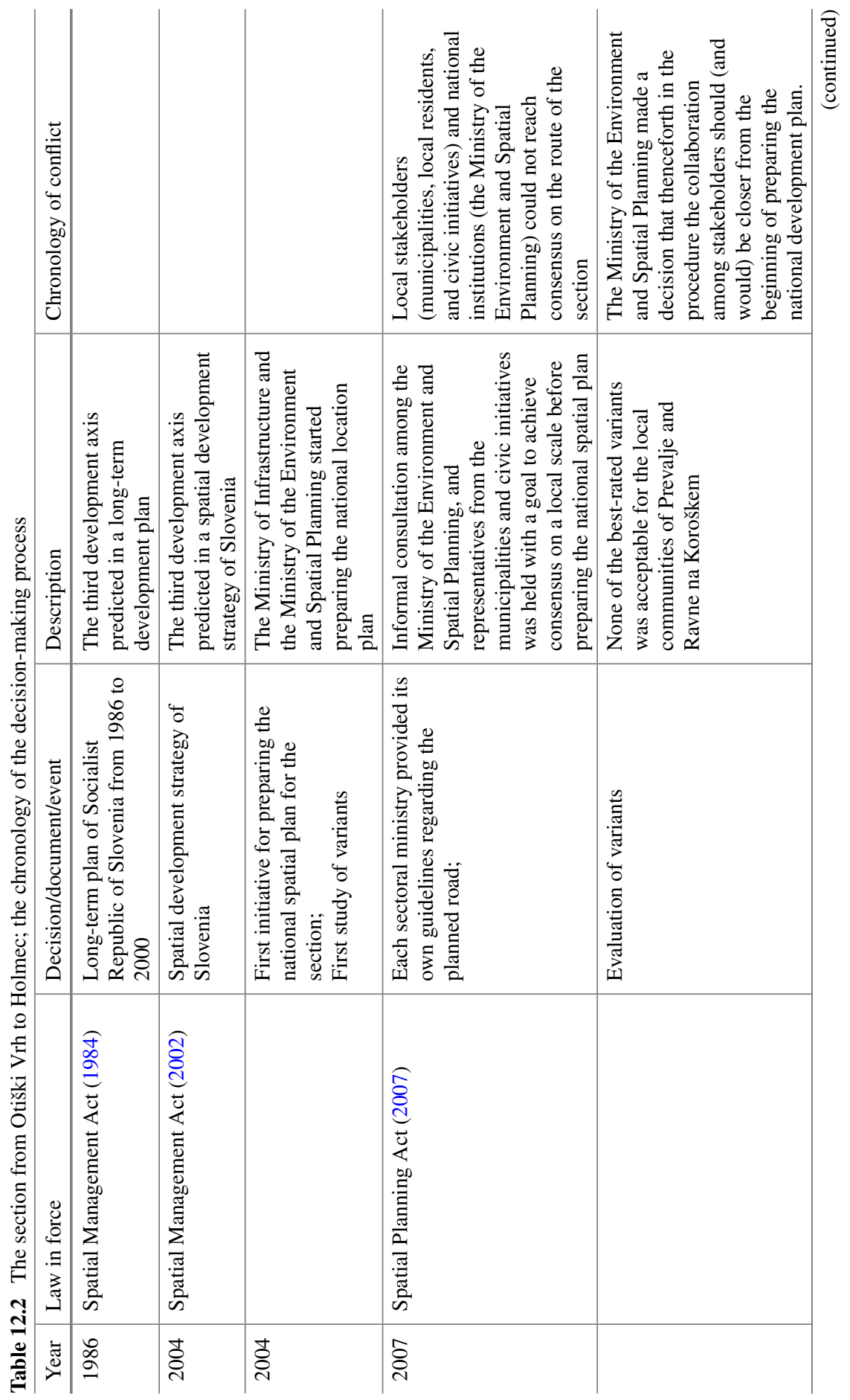


12 Planning Major Transport Infrastructure ...

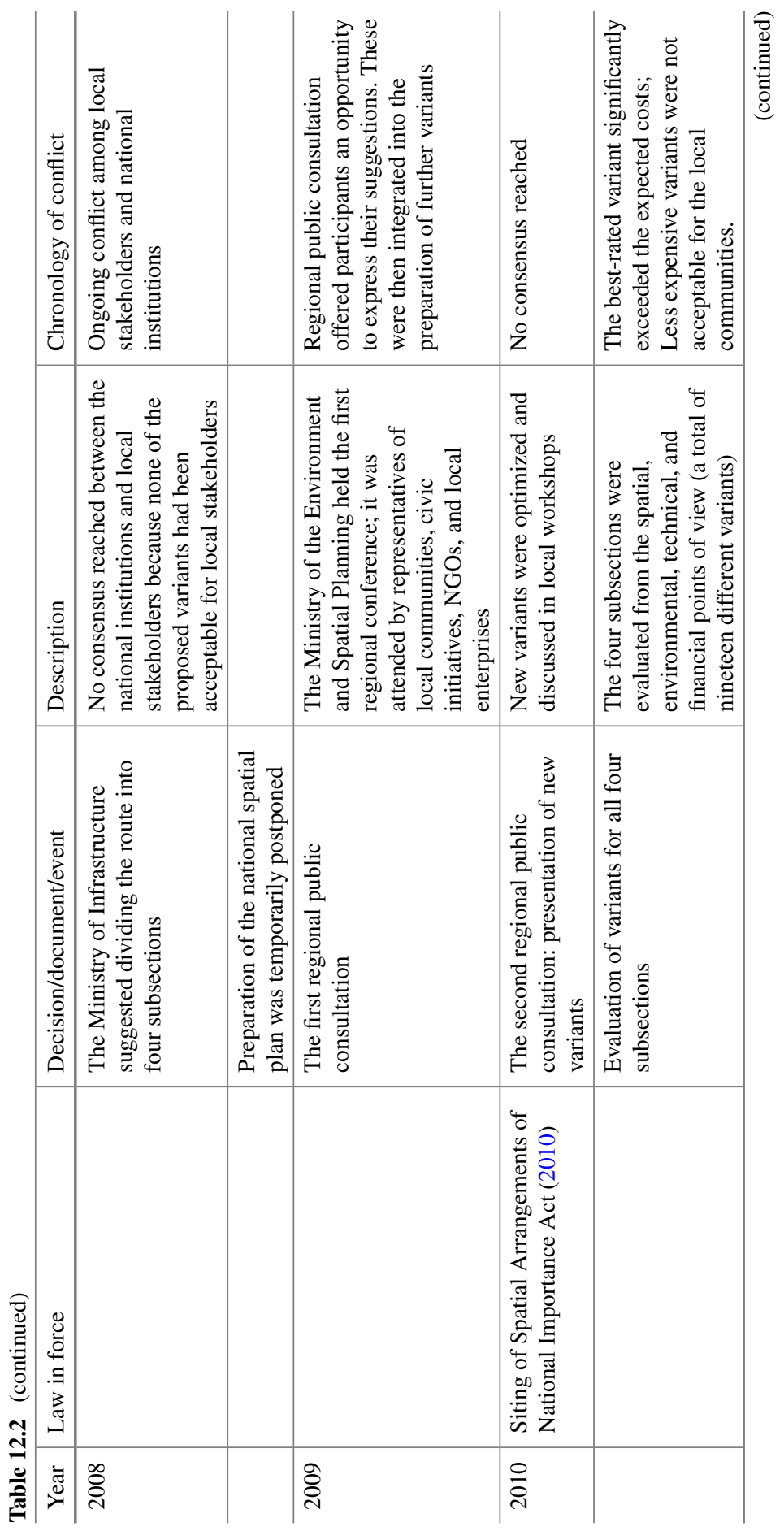




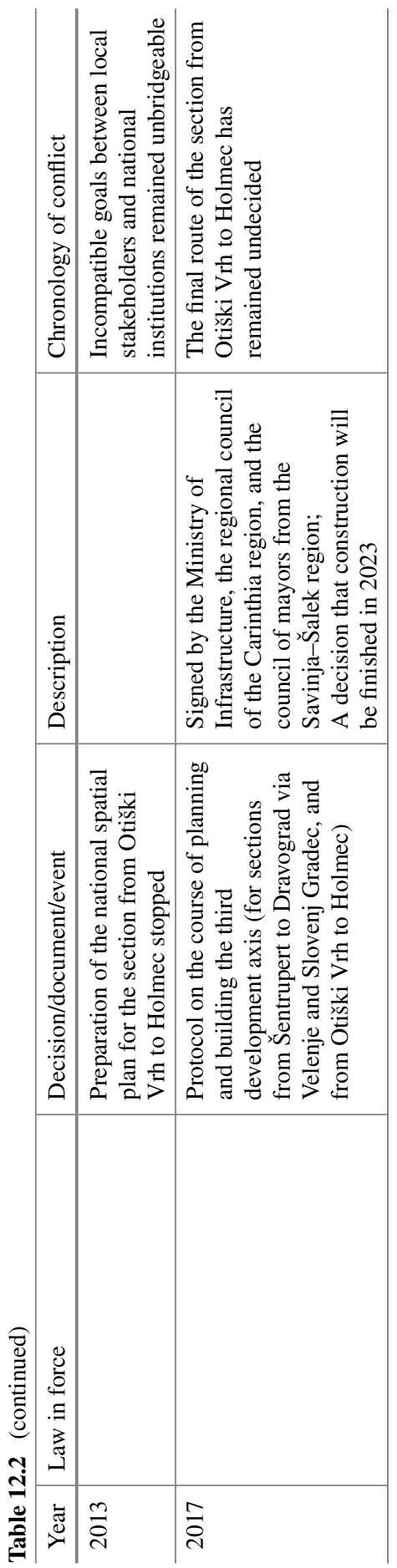


- The Bukovje route, which runs over the hill south of Trebnje, and

- The route behind Trebnje castle, as a middle route between the other two variants.

Key stakeholders involved in the decision-making process were:

- Two civic initiatives, each with a different preference (a group of mainly entrepreneurs from Trebnje that preferred the route alongside Trebnje, and a group of local influential people and experts that preferred the Bukovje route);

- The mayor of Trebnje, who preferred the route alongside Trebnje;

- The municipal council, which preferred the Bukovje route;

- Sectoral ministries; and

- The national freeway company (hereinafter DARS), as the investor, which defended the route alongside Trebnje.

\subsubsection{Second Case Study: The Section from Otiški Vrh to Holmec (the Third Development Axis)}

The second case study is the unfinished process of planning the northern part of the third development axis; namely, the section from Otiški Vrh to Holmec. This decision-making process was a precedent in Slovenia regarding the inclusion of stakeholders in the decision-making process. Due to several conflicts accompanying the decision-making procedures and the anti-inclusionary spatial planning legislation, the Ministry of the Environment and Spatial Planning made an important step forward toward more participative, inclusionary planning practice. They decided to hold three regional conferences during the preparation of the national spatial plan where the public was able to participate, influence the final decision, and thus contribute to more a democratic and more legitimate decision-making process and final decision.

Key stakeholders:

- Municipalities;

- Ministries;

- Representatives of enterprises;

- Representatives of local communities;

- Several civic initiatives; and

- Local residents.

\subsubsection{Case Studies' Comparison}

The two case studies of infrastructure planning in Slovenia show how approaches to stakeholder inclusion in decision-making procedures changed over time. Most 
of the first case study planned before the public hearing was legally an obligatory part of the planning process (only after 2002). Technically, this process shows only the vague outline of participatory practice. Even though the planning procedure was clearly organized top-down, there was cooperation between the national (ministries, DARS) and local administrative levels (the municipality), and the two civic initiatives that emerged during the planning procedure. Local stakeholders that were somehow neglected in the initial stages of the decision-making procedure publicly demanded more inclusionary procedures in the future. One of the most influential stakeholder groups was a civic initiative that preferred the Bukovje route, which significantly influenced the final decision. The civic initiative remained active throughout most of the preparation of the national development plan. Its members responded to (often arbitrary) decisions made by national institutions and successfully articulated their interests. This case study is an example of how even a small group of people, a minority (e.g., a civic initiative), can be influential and can oppose more influential governmental institutions at a national and local level, and even the majority of municipal residents, according to DARS's inquiry. Today, it is meaningless to argue which option for the section from Pluska to Ponikve was better for the Municipality of Trebnje, but the fact is that the final decision was somehow imposed by a minority, the civic initiative. Larger infrastructure projects are always imbued with such power relations that can significantly influence final decisions. The state (the responsible national institutions), however, still bears the responsibility to make decisions that are the most appropriate, even if consensus is not possible. The final decision was made based on the principle of the "lesser evil." Both options had their supporters and opponents, as well as advantages and disadvantages. The decision was the result of pressures made by the civic initiative on the one hand and the result of searching for a less contentious option that would be more easily realized on the other. The fact that this section was one of the last sections of the Slovenian freeways built, and that it needed to be resolved as soon as possible, simply facilitated the decision that would be able to be easier to implement.

The majority of the second case study was planned at a time when the public hearing was removed from planning legislation (after 2007), and it continued after it was obligatory for planning objects of national interest (after 2010). Despite unfavorable legal conditions for stakeholder participation, the Ministry of the Environment and Spatial Planning decided on more inclusionary practice and encouraged stakeholder participation earlier in the decision-making process for the section from Otiški Vrh to Holmec. For this purpose, they pledged to hold several regional conferences on a local scale throughout the decision-making process with an attempt to reach a more locally accepted and legitimate final decision. Despite good intentions, the decisionmaking process still does not have an epilogue. Regional conferences, which were held with the goal of reaching consensus in the local environment, have not yet resulted in a consensual decision. The variant that is acceptable for local residents is economically unfeasible, and the best-evaluated variant was not approved by local communities. The future route of this section thus still remains uncertain.

As both case studies reveal, infrastructure planning is time-consuming and is an ideologically, politically, and financially biased task that demands much cooperation 
and active participation of stakeholders. Undoubtedly, participation in infrastructure planning brings many advantages, but it can be accompanied by several obstacles that make participative processes demanding to carry out.

There are many well-known advantages to participatory planning that make participation of stakeholders a compulsory part of each legitimate infrastructure planning procedure. First, the participation of stakeholders is practically the only possible way that makes it possible for stakeholders to discuss their ideas, viewpoints, demands, and priorities. Deliberation among stakeholders makes space for new (sometimes better) suggestions and exchange of opinions, and it is the only way to better mutual understanding. Second, as the two case studies revealed, the level of participation throughout the planning procedure partly depends on legislation, which sets certain demands regarding stakeholder inclusion. It is largely contingent on stakeholders' commitment to participate on the one hand and to allow participation on the other. Even the absence of regulations that demand or limit stakeholder participation does not necessarily mean that the decision-making process will be arbitrary or enforced by national institutions. The second case study shows that the incentive for participation can originate from a need, from experiences that prove that participation is necessary in order to make decisions that are better accepted in public, especially in the local environment, among people that are or will be most affected by the newly planned (or built) infrastructure.

What the two case studies also show are some hindrances that accompany participatory decision-making procedures in infrastructure planning. There are three main obstacles that hinder stakeholder participation in infrastructure planning in Slovenia: (1) spatial legislation, (2) a lack of criteria to restrain power, and (3) the absence of a regional administrative level. First, Slovenian spatial legislation has been distinctively unfavorable for stakeholder participation, especially after 2007, when the public hearing was no longer a compulsory part of the decision-making process. The main reason for this was an attempt to accelerate planning procedures, but in practice, this measure was far from realizing its purpose. Even the reintroduction of the public hearing for projects in the national interest in 2010 proved that it is not an entirely sufficient measure. The participation of the general public is still made possible too late in the planning procedure. This can trigger opposition in the local environment because municipalities and other stakeholders at the local level do not have a voice in the initial stages of planning procedures. Second, major infrastructure projects are usually politically biased and demand great financial resources. There are generally a large number of stakeholders differing significantly in terms of power (political, economic, financial, informational, etc.) and preferences (which can be very personal or collective), making harmonizing interests extremely demanding. The state has a twofold role in the decision-making procedure. It functions as a stakeholder (representing national interests) on the one hand, and as an "ombudsman" that must provide equal rights of stakeholders to participate in planning procedures on the other. As such, it has no clear criteria for sorting out interests (e.g., public support), which leads to the risk of illegitimate decisions biased by political and elites' interests on the one hand or leads to conflict and deadlock on the other. The third obstacle, which is especially problematic for infrastructure planning, is the absence of a regional 
level in the spatial planning system. Major transport infrastructure not only affects the local environment and community that live in the very vicinity of the planned new route, but is also an inter-municipal and national matter. The regional public consultations that were held in the second case study are evident proof that such consultations are necessary, but they were clearly held too late in the decision-making process (after the variants were already created) and thus ineffective. Despite the fact that the Spatial Planning Act 2 (2017) again introduced a legal basis for preparing regional plans, it is still not an obligatory document. For now, it is also still uncertain how detailed regional plans will be regarding the route itself as well as the expert study on the feasibility of various options.

\subsection{Discussion and Conclusion}

This chapter examined infrastructure planning with conflict and its resolution process (which is more or less participative). Conflicts as an integral part of infrastructure planning demand the participation of stakeholders in order to reach legitimate decisions. The two case studies reflect approaches to infrastructure planning in Slovenia that adapted to the planning legislation in force, and also to national institutions' interest in including stakeholders in decision-making processes. Infrastructure planning in Slovenia can be seen through the lens of path dependency. Slovenian spatial planning legislation and the national institutions involved in infrastructure planning show that the spirit of tokenistic participation from the past political regime has survived the transition from communism. Slovenian planning legislation has been distinctively unfavorable to participation. It has not only neglected the existence of different interests but has also underestimated the importance of stakeholder participation in decision-making processes. The exclusion of the public hearing for the sake of faster decision-making was a clear sign of ignoring the plurality of (conflicting) interests, which Hillier (2003) termed "agonistic pluralism." Conflict is often interpreted as the consequence of a democratic deficit, but some researchers in agonistic planning theory even acknowledge conflict as a prerequisite for democracy (e.g., Marres 2005, 2007; Metzger and Oosterlynck 2015). Instead of acknowledging the agonistic pluralism of interests and properly incorporating and managing them within the planning procedure as an inevitable and essential part of infrastructure planning, conflict is somehow construed as undesirable, something that should be avoided. Although the Ministry of the Environment and Spatial Planning has made some promising steps toward more inclusive decision-making processes in recent years, some stakeholders are still included in the planning procedure too late, when their power to influence the final decision is already limited to few variants prepared in advance.

This chapter discussed the benefits and limitations that have accompanied infrastructure planning in Slovenia. The analysis of two case studies showed that institutions involved in infrastructure planning are making some progress toward more inclusionary practices, but spatial planning legislation does not provide adequate 
support for infrastructure planning regarding stakeholder participation. There is certainly some room for more in-depth qualitative research on the highly versatile power relations that are impossible to neutralize in infrastructure planning and on how to manage such asymmetric interests within the decision-making processes. There is also the problem of exclusion. Spatial planning can never be fully inclusive, and some reduction of interests is needed in order to reach a decision (i.e., the first case study) or the decision-making process cannot be completed (i.e., the second case study). There is always a gap between many desirable solutions and a few possible solutions. Moreover, there will always be some values or views that will be repressed or excluded. As Hillier (2003) stated, any decision requires some form of sorting values. More in-depth research could also provide a better understanding of how to manage highly versatile power relations and interests within decision-making and policy-making procedures and the extent to which stakeholder participation should be prescribed by law. The two case studies and some other experiences from Slovenia and abroad (e.g., spatial development strategies of the Municipality of Idrija, the Austrian regions of Vorarlberg and Tyrol, informal initiatives in Switzerland that assist in participatory policy-making at the national and regional levels, and congestion taxes in Oslo and Gothenburg; Nared et al. 2015; Nared 2019) prove that participation is an integral part of each decision-making and policy-making process. A lack of communication and participatory processes is not solely a problem of post-communist countries, but can be found anywhere, even in countries with a long democratic history, such as Sweden. Implementing congestion tax, consensually accepted in Oslo, Norway, failed in Gothenburg, Sweden, mainly due to the meager inclusion of civil society in the decision-making process. As practices in Slovenia and abroad show, participation is interest-driven to a large degree, even if it is not legally binding.

Acknowledgements The author thanks the Slovenian Research Agency for funding the core program Geography of Slovenia (P6-0101) and the junior researchers postgraduate research program. Both funds provided support for publishing these findings.

\section{References}

Arnstein SR (1969) A ladder of citizen participation. J Am Inst Planners 35(4):216-224. https:// doi.org/10.1080/01944366908977225

Bartos OJ, Wehr P (2002) Using conflict theory. Cambridge University Press, Cambridge

Bowen GA (2009) Document analysis as a qualitative research method. Qual Res J 9(2):27-40. https://doi.org/10.3316/QRJ0902027

Coman R, Tomini L (2014) A comparative perspective on the state of democracy in central and Eastern Europe. Europe-Asia Studies 66(6):853-858. https://doi.org/10.1080/09668136.2014. 905384

Committee on Spatial Development (1999) European spatial development perspective. Towards balanced and sustainable development of the territory of the European Union. Available via European Commission. http://ec.europa.eu/regional_policy/sources/docoffic/official/reports/pdf/ sum_en.pdf. Accessed 12 Oct 2018 
Crescenzi R, Rodrigues-Posé A (2012) Infrastructure and regional growth in the European Union. Pap in Regional Sci 91(3):487-513. https://doi.org/10.1111/j.1435-5957.2012.00439.x

Dühr S, Colomb C, Nadin V (2010) European spatial planning and territorial cooperation. Routledge, London

European Commission (2011) White paper on transport. Available via European Commission. https://ec.europa.eu/transport/sites/transport/files/themes/strategies/doc/2011_white_paper/ white-paper-illustrated-brochure_en.pdf. Accessed 10 Dec 2018

Flyvbjerg B, Bruzelius N, Rothengatter W (2003) Megaprojects and risk: An anatomy of ambition. Cambridge University Press, Cambridge

Hillier J (2003) Agonizing over consensus: Why Habermasian ideals cannot be real. Planning Theory 2(1):37-59. https://doi.org/10.1177/1473095203002001005

Karppinen K, Moe H (2014) What we talk about when we talk about document analysis. In: Just N, Puppis M (eds) Trends in communication policy research. New theories, methods and subjects. Intellect, Bristol, pp 134-145

Kos D (2002) Praktična sociologija za načrtovalce in urejevalce prostora. Založba FDV, Ljubljana Kos D (2003) Postmoderno prostorsko planiranje. Teorija in praksa 40(4):647-657

Luthar B, Pušnik M (2017) The restoration of capitalism after Yugoslavia: Cultural capital, class and power. In: Jelača D, Kolanović M, Lugarić D (eds) The cultural life of capitalism in Yugoslavia: (Post)socialism and its other. Palgrave Macmillan, Cham, pp 81-100. https://doi.org/10.1007/ 978-3-319-47482-3_5

Marres N (2005) No issue, no public: democratic deficits after the displacement of politics. Doctoral dissertation. Department of Philosophy, University of Amsterdam, Amsterdam

Marres N (2007) The issues deserve more credit: Pragmatist contributions to the study of public involvement in controversy. Soc Stud Sci 37(5):759-780

Metzger J, Oosterlynck S (2015) The contested terrain of European territorial governance: New perspectives on democratic deficits and political displacements. In: Metzger J, Allmendinger P, Oosterlynck S (eds) Planning against the political: democratic deficits in European territorial governance. Routledge, Abingdon, Oxon, pp 2-28

Nared, J (ed) (2019) Transforming European metropolitan regions. Smart mobility for better liveability. Založba ZRC SAZU, Ljubljana. Available via Založba ZRC SAZU. https://zalozba.zrc-sazu. si/sites/default/files/transforming_european_metropolitan_regions.pdf. Accessed 28 Apr 2019

Nared J, Razpotnik Visković N, Cremer-Schulte D, Brozzi R, Cortines Garcia F (2015) Achieving sustainable spatial development in the Alps through participatory planning. Acta geographica Slovenica 55(2):363-373. https://doi.org/10.3986/AGS.1631

Nared J, Hudoklin, J, Kavaš, D, Zavodnik Lamovšek, A (2019) Integration of Spatial and Development Planning at the Regional Level in Slovenia. Založba ZRC, Ljubljana. Available via Založba ZRC SAZU. https://zalozba.zrc-sazu.si/sites/default/files/gr29.pdf. Accessed 6 May 2019

National freeway construction program (1995) Uradni list RS 13/96. Available via PISRS. http:// www.pisrs.si/Pis.web/pregledPredpisa?id=NACP12. Accessed 12 Oct 2018

Offe C (1997) Varieties of transition-The east European and East German experience. The MIT Press, Cambridge, MA

Perić A (2016) The evolution of planning thought in Serbia: Can planning be "resilient" to the transitional challenges? In: History urbanism resilience: Planning theories, pedagogies and practices. Proceedings of the 17th International Planning History Society conference, Delft, July 2016. Int Plan Hist Soc Proc 17(7):181-194. https://doi.org/10.7480/iphs.2016.7

Peters D (2003) Cohesion, polycentricity, missing links and bottlenecks: Conflicting spatial storylines for pan-European transport investments. Eur Plan Stud 11(3):317-339. https://doi.org/10. $1080 / 09654310303638$

Pogačnik A (2005) Prispevek k integraciji prostorskega, socialnega, gospodarskega in okoljskega načrtovanja. Dela 24:49-59

Ravbar M (2007) Spatial planning_What for? Geodetski vestnik 51(2):233-245

Ravbar M (2016) Regions-A tool for communication? (An opportunity for more effective regional planning). IB Revija 50(2):83-87 
Regional spatial plan for the territory of the SR Slovenia. Situation in space and development tendencies. 1970. Biro za regionalno prostorsko planiranje, Ljubljana

Regional and Spatial Planning Act (1967) Uradni list SRS 16/1967. Ljubljana

Saje M (1967) Principles of the law on the regional space planning. Gradbeni vestnik 6(7):124-129

Salet W, Bertolini L, Giezen M (2012) Complexity and uncertainty: problem or asset in decisionmaking of mega infrastructure projects? Int J Urban Reg Res 37(6):1984-2000. https://doi.org/ $10.1111 / \mathrm{j} .1468-2427.2012 .01133 . x$

Siting of spatial arrangements of national importance act (2010) Uradni list RS 80/10. Available via PISRS. http://www.pisrs.si/Pis.web/pregledPredpisa?id=ZAKO5830. Accessed 12 Oct 2018

Škarabot J (2002) Primeri iz prakse. Programi in postopki vključevanja interesnih skupin na Uradu RS za prostorsko planiranje. In: Marega M, Kos D (eds) Aarhuška konvencija v Sloveniji: strokovna priporočila za implementacijo Konvencije o dostopu do informacij, udeležbi javnosti pri odločanju in dostopu do pravnega varstva v okoljskih zadevah. Ljubljana, Regionalni center za okolje za srednjo in vzhodno Evropo, pp 111-114

Spatial development strategy of Slovenia (2004) Available via MOP. http://www.mop.gov.si/ fileadmin/mop.gov.si/pageuploads/podrocja/prostorski_razvoj/SPRS_angleska_verzija.pdf.

Accessed 22 May 2019

Spatial management act (1984) Uradni list SRS 15/1984. Ljubljana

Spatial management act (2002) Uradni list RS 110/02. Available via PISRS. http://www.pisrs.si/ Pis.web/pregledPredpisa?id=ZAKO1581. Accessed 12 Oct 2018

Spatial planning act (2007) Uradni list RS 33/07. Available via PISRS. http://www.pisrs.si/Pis.web/ pregledPredpisa?id=ZAKO1581. Accessed 12 Oct 2018

Spatial planning act 2 (2017) Uradni list RS 61/17. Available via PISRS. http://www.pisrs.si/Pis. web/pregledPredpisa?id=ZAKO7341. Accessed 28 Apr 2019

Spatial planning act in transition (1990) Uradni list RS 48/90. Available via PISRS. http://pisrs.si/ Pis.web/pregledPredpisa?id=ZAKO21. Accessed 12 Oct 2018

Thomas M (1998) Thinking about planning in the transitional countries of central and eastern Europe. Int Plan Stud 3(3):321-333. https://doi.org/10.1080/13563479808721717

Vlaj S (1998) Lokalna samouprava. Založba FDV, Ljubljana

Vujošević M, Nedović-Budić Z (2006) Planning and societal context-The case of Belgrade, Serbia. In: Tsenkova S, Nedović-Budić Z (eds) The urban mosaic of post-socialist Europe. Contributions to economics. Physica-Verlag, Heidelberg, eBook, p 275-294. DOI:https://doi.org/10.1007/37908-1727-9_14

Open Access This chapter is licensed under the terms of the Creative Commons Attribution 4.0 International License (http://creativecommons.org/licenses/by/4.0/), which permits use, sharing, adaptation, distribution and reproduction in any medium or format, as long as you give appropriate credit to the original author(s) and the source, provide a link to the Creative Commons licence and indicate if changes were made.

The images or other third party material in this chapter are included in the chapter's Creative Commons licence, unless indicated otherwise in a credit line to the material. If material is not included in the chapter's Creative Commons licence and your intended use is not permitted by statutory regulation or exceeds the permitted use, you will need to obtain permission directly from the copyright holder.

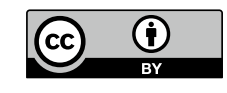

